\title{
W. Sunderland
}

\section{THE USSR AS A MULTINATIONAL STATE FROM THE REVOLUTION TO THE DEATH OF STALIN: WESTERN SCHOLARSHIP SINCE 1991*}

This review article examines predominantly English-language research since 1991 on the history of the USSR as a multinational state from 1917 to the end of the Stalin era. Influenced by the rising role of nationality in late Soviet life, the opening of Soviet archives during the Perestroika period, and new developments in the conceptualization of the nation in different disciplines, Western scholarship on the history of the national question in the Soviet Union expanded considerably in the 1990s and is now one of the most vibrant areas of historical research in the Soviet history field. The essay's central claim is that new research since the end of the Cold War has considerably revised the study of the nationality policies of the early Soviet state, underscoring that the USSR was a paradoxical nationality project that simultaneously engaged in both the construction and the selective undermining and destruction of national identities. Refs 155 .

Keywords: USSR, nationality policy, national identity, interethnic relations, historiography.

\section{У. Сандерленд}

\section{СССР КАК МНОГОНАЦИОНАЛЬНОЕ ГОСУДАРСТВО ОТ РЕВОЛЮЦИИ ДО СМЕРТИ СТАЛИНА: ЗАПАДНАЯ ИСТОРИОГРАФИЯ С 1991 ГОДА}

В статье анализируется преимущественно англоязычная историография, посвященная Советскому Союзу как многонациональному государству в период его существования с 1917 г. до 1953 г., конца сталинской эпохи. Рассмотрены работы, опубликованные со времени распада СССР до настоящего времени. В 1990-е годы под влиянием возросшей роли национального вопроса в конце советской эпохи, открытия советских архивов в период перестройки, а также под воздействием новых идей и разработок в этноконфессиональном исследовательском поле в разных дисциплинах западная историография национального вопроса в Советском Союзе достигла значительного прогресса и сейчас является одним из самых развивающихся направлений исторических исследований в области советской истории. Главная идея обзора состоит в том, что в исследованиях, увидевших свет после окончания «холодной войны», подвергнута серьезной переоценке национальная политика в первые годы советской власти. В них подчеркивается, что СССР представлял собой парадоксальный национальный проект, который одновременно стремился, с одной стороны, к конструированию новых советских наций, с другой - к селективному подрыву и разрушению национальных идентичностей. Библиогр. 155 назв.

Ключевые слова: СССР, национальная политика, национальная идентичность, межэтнические отношения, историография.

When the Soviet state came to an end in 1991, an era of Western historical research ended as well. Prior to this turning point, the study of nationality issues in the Soviet context was at best secondary. ${ }^{1}$ The abiding concerns - and the great controversies - of the

Sunderland Willard - PhD, Professor, University of Cincinnati, USA; Visiting Research Fellow, St. Petersburg Institute of History RAS, 7, ul. Petrozavodskaia, St. Petersburg, 197110, Russian Federation; sunderwd@ucmail.uc.edu

Сандерленд Уиллард - PhD, профессор, Университет штата Цинциннати (США); приглашенный исследователь, Санкт-Петербургский институт истории РАН, Российская Федерация, 197110, Санкт-Петербург, ул. Петрозаводская, 7; sunderwd@ucmail.uc.edu

* This research was supported by grant N 15-18-00119 from Russian Science Foundation.

Исследование выполнено за счет гранта Российского научного фонда (проект № 15-18-00119).

${ }^{1}$ On the limited role traditionally allotted to nationality issues in the grand narratives of Russian and Soviet history, see [Hagen 2004, p. 448: Jennison E. W. Jr. 1975, p. 437-451].

(c) Санкт-Петербургский государственный университет, 2016 
field lay elsewhere. What was the nature of the Russian Revolution? Did Leninism have to result in Stalinism? How did Stalin's dictatorship function? Was the Soviet Union a totalitarian state? If so, when and how did Soviet totalitarianism begin? Nationality issues figured in the answers offered to these questions, but not in a defining sense. By the 1970s, the field of Soviet history, in the US and to a lesser degree in Europe, was divided between practitioners of the so-called "social history school" and more traditionally defined political historians, and neither group treated the "national question" as integral to the study of the Soviet experience.

In retrospect, this seems a glaring oversight. The eruption of interethnic tensions during the Perestroika years proved beyond all doubt that nationality was central to Soviet politics and society in the last Soviet decade, and the voluminous historiography on the USSR as a multinational state that has transformed the field since 1991 makes it clear that this was the case throughout the Soviet era. Yet at the time the neglect of nationality as a historical topic seemed less obvious. Few Western historians questioned their habit of prioritizing class over ethnic factors. Those conducting research in the USSR were also obliged to follow the dictates of their Soviet minders, which invariably meant working exclusively in Moscow and Leningrad rather than in the "national periphery" and rarely, if ever, working in archives. Imperial-era specialists generally had at least selective access to archival collections. Soviet-era specialists, by comparison, faced greater restrictions. Given the perceived sensitivity of the subject, archival research by Western historians on nationality-related subjects was all but impossible.

The change brought about by 1991, in that sense, was indeed remarkable, since it quickly led to a revolution in archival access, among other things. (See below.) Yet it would be wrong to conclude that the end of the USSR in and of itself created the "imperial turn" and the abiding interest in nationality issues that now preoccupies the field. ${ }^{2}$ In fact, research on Soviet nationality policy had already been established as a part of Western scholarship for at least a half-century. As early as the 1950s, Richard Pipes, then an assistant professor at Harvard, wrote an influential book underscoring what he saw as the dynamic of conquest that created the USSR, while other scholars, many of them émigrés, also stressed the critical importance of Soviet nationality issues [Pipes 1954]. One example: the small but influential school of specialists on Soviet Islam that coalesced around the St.-Petersburg-born Orientalist Alexandre Benningsen at the École des Hautes Études en Sciences Sociales in Paris between the 1960s and the 1980s. ${ }^{3}$ Another: the Hoover Institution, a leading US center for Soviet Studies during the Cold War era, whose book series devoted to narrative histories of "Soviet nationalities" helped define the field of Soviet "ethnic minority" or "nationality studies" in the West in the late 1970s. The socalled "Hoover books" - on the Georgians, the Volga Tatars, the Kazakhs, the Estonians, and other peoples besides, all written by leading authorities - quickly emerged as classics of their genre. ${ }^{4}$

2 On the "imperial turn," see [David-Fox, Holquist, Martin 2006, p. 705-712]. Regarding the tendency to exaggerate the paradigmatic shifts of 1991, see [Young 2007, p. 95-122].

3 For Alexandre Benningsen's principal works, see: [Benningsen 1960; Benningsen 1961; Benningsen 1967; Benningsen, Wimbush 1970; Benningsen, Wimbush 1985; Carrère d'Encausse 1963; Carrère d'Encausse 1978].

4 For a comprehensive review of the series up to 1991, see [Laitin 1991, p. 139-177]. 
The logic of "nationality studies" as enshrined in the Hoover series was a seemingly straightforward reflection of Soviet realities. The USSR was a multinational union; it followed, then, that each nation within the union (in particular, the so-called "titular peoples" identified with the USSR's fifteen union-level republics) deserved their own narrative history. The sole exception was the Russian nation, which, as the dominant nationality in the mix, was far better known than any of the others and was therefore judged as not requiring special study. "Nationality studies" in this context thus effectively meant the study of "non-Russian" nationalities, with a particular stress on how the histories of these groups distinguished them from the Russians. Politicians and commentators in the West often used the terms "Russian" and "Soviet" interchangeably, thus implicitly obscuring the great ethnic diversity of the Soviet state. Scholarship in "nationalities studies" was meant to challenge this lazy thinking by situating national diversity at the very heart of the way Western specialists studied the USSR. ${ }^{5}$

This approach had the obvious benefit of exposing historians to a rich diversity of non-Russian sources and of offering a far more inclusive view of the role of the national peripheries in shaping the Soviet experience. Indeed, one of the great plusses of nationalities research was to diminish - at least somewhat - the overwhelmingly Moscow and St. Petersburg-centric quality of writing on Russian and Soviet history.

This said, however, the Hoover series approach also reflected clear biases and limitations. For one, in keeping with the larger presumptions of the field, works in the series often reduced Soviet history to a binary duel of "Russians" versus "others," usually implying in the process that the Russians ruled the state from the center, while the non-Russians resisted in the periphery. Western-based specialists, including émigré scholars, likewise tended to depict both Tsarist Russia and the USSR as colonial empires defined by exploitative or, at a minimum, overbearing policies that threatened and/or, depending on circumstances, expressly sought to undermine minority peoples. Of the two polities, the Soviet order seemed by far the worst since the Communists were not only anti-nationalist but also anti-national, to the point, it was argued, of targeting Ukrainians and Kazakhs for destruction during collectivization and deporting a long list of other nationalities in the closing years of World War II. ${ }^{6}$ Surveying much of the Western writing of the 1960 s and 1970s (if not the 1980s as well), one gets the impression that if national diversity managed to survive in the USSR, it was largely the doing of the minority peoples themselves. The title of Turkic specialist Azade-Ayşe Rorlich's contribution to the Hoover series is revealing in this respect: The Volga Tatars: A Profile in National Resilience [Rorlich 1986].

Finally, for all of the value that came from singling out the importance of national issues in the Russian and Soviet past, the emphasis of "nationalities" research fell, understandably enough, on the history of the nation, and this in turn, led to the inculcation of some of the teleologies and prejudices associated with national history. Thus few specialists in the Soviet nationalities field questioned the apparent naturalness of the nation as an ethno-territorial form or, for that matter, the overall narrative that held that all nations, sooner or later, should have states of their own. The widely held view was that na-

${ }^{5}$ For helpful overviews of nationality studies prior to 1991, see [Suny 1995, p. 105-147; Olcott 1995, p. 135-148].

${ }^{6}$ Emphasis on the Stalin era as a time of "nation-destroying" comes through most clearly in Robert Conquest's The Nation Killers: The Soviet Deportation of Nationalities [Conquest 1970;]; and The Harvest of Sorrow: Soviet Collectivization and the Terror-Famine [Conquest 1987]. 
tions, while not timeless features of the human landscape, were nonetheless historically real and objective. They were collectivities that emerged in verifiable historical conditions and possessed concrete and largely stable historical characteristics. Ironically, in viewing nationality this way, Western specialists found themselves in broad agreement with Bolshevik nationality experts like Joseph Stalin whose famous 1913 article on "Marxism and the National Question" proposed a roughly analogous view. ${ }^{7}$ But this shouldn't be surprising. By the cusp of the 1990s, the mark of nationality on everyday life was so pervasive that it was largely naturalized. In the eyes of everyone concerned - nationalists, socialists, and writers of national history alike - nations appeared as objective entities to be defined, measured, and compared, and with interests and limitations that had to be studied and accounted for.

Approaches to the USSR's history as a multinational state began to change dramatically in the 1990s for three basic reasons. The first and arguably most important was the simple reality of the end of the Soviet Union. Perestroika shifted issues of nationality to the front burner of Soviet life. In 1995, just four years after the collapse of the USSR, former Soviet Premier Mikhail Gorbachev recalled that, having grown up in the North Caucasus, he had known from the start "how important it was to demonstrate a delicate and cautious touch in handing [nationality] issues." [Gorbachev 1995, p. 18]. Yet as it turned out, for all his caution, Gorbachev appears to have woefully underestimated the explosive potential of national grievance. As a result, almost as soon as his democratic and economic reforms began, interethnic tensions and nationalist movements began rising as well. $\mathrm{Na}-$ tional groups across the USSR protested their treatment by the Soviet government. Popular fronts took over in the Baltic republics. Bloody interethnic violence exploded in the Caucasus. Soviet power in Eastern Europe crumbled away.

In less than six years - from the start of the $27^{\text {th }}$ Congress of the CPSU in January 1986 to the formation of the Commonwealth of Independent States in December 1991 the USSR passed from reform to extinction. Nationality issues were not the only factor that influenced this path, but they were among the most important. Given the sheer scale and speed of the emergence of nationalist politics in late Soviet society, there was simply no way for historians not to ask how and why this had come to pass. Indeed, the first postSoviet attempts to explain the particulars of Soviet national history took place against the immediate backdrop of unfolding events.

A second key factor was the opening of the archives. Even before the unravelling of the USSR, access to Soviet archives began to improve for Western scholars. Then, once the end came, the doors truly swung open, both in Russia as well as in many of the other former republics. Serious limitations remained, of course. Some new countries made materials far more open than others. Certain Western historians rightly warned of the danger of losing one's professional way in the "gold-rush" of the times [Hagen 1993, p. 96-100]. Others pointed to the practical and methodological challenges "imposed by the organization of the archives themselves" and were skeptical about how much the new archival

7 Stalin's pithy definition of the nation: "a historically constituted, stable community of people, formed on the basis of a common language, territory, economic life, and psychological make-up manifested in a common culture." See the text of his article at https://www.marxists.org/reference/archive/stalin/ works/1913/03a.htm\#s1 (last consulted March 2016). For the Russian originals, see [Natsional'nyi vopros 1913; National'nyi vopros i marksizm 1914]. 
access was likely to deliver in terms of reinterpretations for the field ${ }^{8}$. But the net effect of the "archival revolution" was profound all the same. As Director Sergei Mironenko of GARF suggested in 1993, "Documents hidden...for decades" were now emerging to help explain "why Russia chose one...path of development rather than another" [Chernetsky 1993, p. 841]. Document collections poured forth from Russian repositories as archives themselves became de facto publishing houses ${ }^{9}$. More importantly, by now it seemed normal and natural for historians working on national questions to conduct archival work. The restrictions of old were apparently gone for good.

The third important factor that helped change writing on the history of national questions in the USSR was an emerging shift in the study of the nation in areas outside the Russian field. Rigidly primordialist thinking about nationality had long been questioned in Western academia, but now even the "soft" primordialism identified with the Hoover series found itself increasingly challenged by more obviously constructivist assumptions. A new orthodoxy was emerging, one that rejected the idea of nationality as an objective fact, however historically determined, and approached it instead as an inherently subjective and multifaceted form. Nations were thus "made" rather than "born," and much of the new scholarship on the nation emerging in the 1980s focused on documenting and explaining this nation-making process.

The most influential thinkers in this age of "new thinking" were scholars such as Miroslav Hroch, Ernest Gellner, Benedict Anderson, and Anthony Smith, each of whom brought a different disciplinary approach and theoretical emphasis to the issue. Hroch, a Czech political theorist and historian whose work first appeared in German in the late 1960s but obtained broader impact with an English translation in 1985, proposed a sequential theory for understanding the emergence of national movements in the modern era, starting with a stage of scholarly research and discovery (Phase A), then passing through a "period of patriotic agitation" (Phase B), and finally ending with "the rise of a mass national movement" (Phase C). Gellner, a philosopher and social anthropologist, argued for seeing nationalism as a product of industrialization, linking it explicitly to the phenomenon of nineteenth and twentieth-century modernity. Anderson, a political scientist specializing in Southeast Asia, underscored the importance of language, symbols, and the collective imagination in shaping national identity, all of which he, too, like Gellner, associated with the advent of the modern age, specifically the era of print capitalism. Smith, by contrast, drew on his formation as a historical sociologist to stress the premodern or ethnic bases of nations, arguing that proto-national identification in multiple areas across the world emerged long before the modern era ${ }^{10}$.

Alongside these efforts to reinterpret the nation, new scholarship in what would become known as the field of postcolonial studies offered a similarly provocative rethinking of modern imperialism. A foundational work in this regard was Edward Said's Orientalism, which offered one of the first sweeping scholarly critiques of colonial-based knowl-

${ }^{8}$ On the challenges for researchers that seemed inherent in the organization of Soviet archives, see the comments by Peter A. Blitstein, [Blitstein 1999, p. 125]. For a skeptic's view from the time of what the archival turn was likely to bring, see Stephen Kotkin [Kotkin 1998, p. 392].

${ }^{9}$ For a sampling of the many Russian-language document collections that appeared in the 1990s, see [Blitstein 1999, pp. 307-326].

${ }^{10}$ For the works referenced here, see [Hroch 1985; Gellner 1983; Anderson 1983; Smith 1986; Smith 1991]. 
edge [Said 1978]. ${ }^{11}$ Much like theorists of the nation who emphasized the inherent contingency of national forms, Said insisted that European imperialism was no different. It, too, rested on a self-serving "political vision of reality" that created the West as rational and progressive, while designating other parts of the world, the Muslim "Orient," in particular, as irrational and backward. Thus the study and representation of the Orient in scholarship and the arts was not a neutral exercise but rather a "discourse" inseparable from the "gross political fact" of Western colonial domination [Said 1978, p. 11]. It followed that a full appreciation of the working of empires required confronting and interrogating their inherently constructed, discursive quality, while at the same time engaging the voice of the otherwise silenced or mediated "colonial Other", that is, the non-European, non-White subjects of European empires who were otherwise left out of traditional imperial histories.

The confluence of the peristroika period's nationality politics created the preconditions for a new turn in Western scholarship on the Soviet past with the opening of archives and bubbling up of new thinking on nations, nationalism, and imperial culture from outside the Russian field. In retrospect, one harbinger of the changes to come was the work of Rogers Brubaker, an American historical sociologist from UCLA whose initial research focused on the "politics of citizenship and nationhood" in Germany and France but whose interests by the early 1990s were turning increasingly towards Eastern Europe and the USSR. Brubaker's geographical move seemed to capture something of the scholarly promise of the moment. As he noted in the early 1990s, the break-up of the USSR and the emergence of ethnonationalism in post-Soviet space seemed to suggest (according to the conventional thinking) that the long-repressed national minorities of the Soviet state were finally rising up and claiming the nationhood that Moscow had never allowed them to have, yet the reality, in his view, was more nuanced: "Far from ruthlessly suppressing nationhood, the Soviet regime pervasively institutionalized it. The regime repressed nationalism of course, but at the same time it went further than any other state before or since in institutionalizing territorial nationhood and ethnic nationality as fundamental social categories" [Brubaker 1994, p. 6-7] ${ }^{12}$.

What Brubaker was suggesting, in effect, was that the study of the Soviet case offered a terrain for thinking differently about nations, empires, and national identities. This was a field where one might apply some of the new approaches that scholars such as Gellner and Anderson had begun proposing, asking not what nations were as if they constituted long-existing objective realities but rather how they became institutionalized and acquired social and political meaning at discrete historical junctures. This was the early 1990s. As it turned out, Brubaker was not alone in coming to these conclusions. Other Western specialists on the USSR were moving in the same direction. The so-called "imperial turn" was about to begin.

\section{Scholarship Since 1991}

How should we define this profound transformation in the study of the USSR? One critical aspect of the change is a simple yet striking shift in scale and influence. Prior to the early 1990s, research on questions of ethnocultural diversity in the Russian past was

${ }^{11}$ For context, see Robert Young [Young 2001].

${ }_{12}$ For Brubakers' most influential work on the Soviet context, see [Brubaker 1994, p. 47-78; Brubaker 1996]. 
important but secondary. Since 1991, however, the volume of publication has expanded dramatically and interest in the subject has shifted from the margins "to the center of the field." [David-Fox, Holquist, Martin 2006, p. 705]. Led in large part by the breakthrough work of scholars such as Andreas Kappeler [Kappeler 1982; Kappeler 1994; Kappeler 1993], ${ }^{13}$ Alfred J. Rieber, ${ }^{14}$ and Ronald Grigor Suny, ${ }^{15}$ research on national questions is now a regular feature in all the major periodicals focused on Russian and Soviet history, including $A b$ Imperio, which was founded in 2000 with the express purpose of highlighting the experience of nationality and empire in Russian, Soviet, and post-Soviet space. Books on the subject abound. Historian Stephen Kotkin joked not long ago (only half tongue in cheek): "Apply for a grant on 'borderlands,' and you get the grant even before you hit the send button" [Kotkin 2007, p. 519].

More importantly, the "imperial turn" has changed how historians of Russia and the USSR approach the country's past. The specialist on Polish-Russian history Ted Weeks describes the conceptual reframing of the new scholarship in the following way:

The "imperial turn"...aims to avoid a national teleology in which Russians play the leading (or only) role in the historical narrative, to emphasize the presence and significance of non-Russians in "Russian" (rossiiskaia) history, and to view the Russian Empire and USSR not as would-be nation-states but as empires, a different kind of polity. The imperial turn also wants to problematize the very definition of "Russian," whether meant in an ethnic (russkii) or political-geographical (rossiiskii) sense. The history of "nationality policy," i.e., how the Russian center dealt with non-Russians, belongs here as does the history of non-Russians within the Russian and Soviet state. Finally, a hardly attempted but promising direction would be the comparison of the Russian/Soviet empire with other empires like the French, British, German, or American [Weeks URL: http://www.hsozkult. de/literaturereview/id/forschungsberichte-1134].

The greatest focus on these issues as they relate to Soviet Russia has fallen on the period from the Great War and the Revolution to the end of Stalinism, with special attention given to themes such as: the role of imperial collapse and post-imperial politics in establishing the bases for Soviet ethno-federalism, the politics of nation-building during NEP, and the role of nationality in the evolution and operation of the Stalin dictatorship, in particular regarding the campaigns of the First Five-Year Plan, broader society-building in the 1930s, the Terror, the Gulag system, World War II, and postwar reconstruction. In every case, the central contribution of the new literature has been to insist on situating the national-imperial factor at the heart of Soviet history.

One area where we see this new approach quite clearly is the emerging historiography of Russia's World War I. Studies of the Great War on the Russian side were traditionally overshadowed by the study of the revolution, and among the few studies that did focus on the war, none engaged closely with the imperial dimension - for example, Norman Stone's classic study of the Russian war barely addresses the nationality issue [Stone 1998]. ${ }^{16}$ Scholarship since 1991, however, has both paid more attention to the war

13 For a retrospective by the author, see [Kappeler 2000, p. 15-32].

14 One example from Alfred J. Rieber's rich and influential corpus of work on the imperial context of Russian history prior to the 2000s: [Rieber 1994, p. 61-92; Rieber 2009, p. 227-237].

15 For Suny's early work on nationality questions that established him as a leader in the field, see his classic [Suny 1972; Suny 1988; Suny 1993].

16 Allan K. Wildman's magisterial study of the Russian army in 1917 also pays little attention to nationality issues: The End of the Russian Imperial Army [Stone 1980-1987, 2 vols]. 
in general and to problems of empire in particular, emphasizing the way in which imperial tensions during the war years contributed to the breakdown of central authority and eventually to the de facto "decolonization" of the imperial state. ${ }^{17}$ Some of the best new work in the field has highlighted the inter-imperial nature of the crisis of the time, underscoring the way the war transformed the Russian, Ottoman, and Habsburg borderlands into a shared "shatter zone" of state collapse [Reynolds 2011; Roshwald 2001; Rieber 2014].

Still, the Russian unravelling was unique in that it unfolded in tandem with a fullfledged revolution. In fact, it's perhaps best to describe the revolution that developed in Russia as an imperial revolution since it unfolded within Russian imperial space and was profoundly shaped by the many complexities of the tsarist imperial experience. The new scholarship on 1917 engages this imperial context much more fully than earlier studies, while also dethroning the revolution from its separate perch and merging it into a broader view of the violent change of the times. A key work in this respect is Peter Holquist's influential Making War, Forging Revolution, which focuses on the Don region of Southern Russia and argues that the Great War, Revolution, and Civil War should not be seen as distinct events but rather as interconnecting stages within a single "continuum of crisis," every aspect of which was informed by Russia's regional and multicultural complexity and the larger dynamic of "end of empire" that overlay the period [Holquist 2002] ${ }^{18}$.

Building from this way of thinking, the once relatively tidy story of the Civil War in the imperial periphery has also been reinterpreted. Once depicted by Pipes and others as a Moscow-directed reconquista of the borderlands by the Bolsheviks (a number of Bolsheviks also saw the process this way), the civil war today appears not as a single overarching conflict but rather a concatenation of civil wars in the plural, a different war, in effect, for each periphery. Suny's work, in particular, has done much to illuminate the complex "ebbs and flows of socialism and nationalism" that coursed through the borderlands in the revolutionary period ${ }^{19}$. The result is a far messier but ultimately more compelling picture of how the Bolsheviks prevailed against their enemies across much of Russia's former imperial space. Scholarship since 1991 has also done much to examine the Bolsheviks and other actors of the revolutionary era as "people of empire" - that is, as individuals whose political subcultures and worldviews were shaped in myriad ways by the diverse multicultural environments of the tsarist state [Riga 2014; Jones 2005; Sunderland 2014; Rieber 2001, p. 1677-1691; Suny 2012, p. 243-252; Hallez 2014, p. 119-134]. Still other studies have underscored the influence of tsarist-era "empire specialists," such as Orientalist scholars, ethnographers, missionaries, and colonization experts, on early Soviet institutions [Hirsch 2005; Cadiot 2007; Tolz 2011; Siegelbaum, Moch 2014, p. 32-48; Graber, Murray 2015, p.127-152]. The net effect of this work has been to increase our

17 The key work here is [Sanborn 2015]. For the broader context of decolonization relating to the German occupation of Poland and the Baltic provinces, see [Liulevicius 2005]. On the Central Asian Uprising of 1916 that destabilized tsarist power in Turkestan, see [Happel 2011; Brower 2003, p. 1-25, 152-175]. For additional studies highlighting national-imperial issues during the war period, see Lieven 2015; Lohr 2003; Jahn 1995; Norris 2006; The Empire and Nationalism at War 2014].

18 On "end of empire," see the articles [After Empire 1997].

19 See, in particular [Suny 1993, p. 20-83]. On the complex national and regional dynamics of revolution in different imperial borderlands in the 1917-early 1920s period, see also: [Khalid 1996, p. 270-296; Khalid 2011, p. 145-164; Schafer 2001, p. 165-190; Sanborn 2010, p. 195-213; Buttino 2014, p. 109-136; Cusco 2014 , p. 137-162]. 
appreciation for the complex imperial - or more explicitly, post-imperial - context that ultimately gave rise to the new Soviet order.

It's the distinctive morphology of Soviet power, however, that has arguably drawn the most attention from scholars since 1991. In part, this is because of the post-imperial anomaly presented by the Soviet case. The two other great dynastic empires of continental Europe - the Habsburgs and the Ottomans - disappeared in the aftermath of World War I. The Russian Empire, however, lived on, in a manner of speaking, in the new form of the USSR. Finland was lost for good. The Baltic provinces and Russian Poland broke away to form independent states until the Soviet occupation ushered in by the Nazi-Soviet Pact of 1939. But most of the rest of the old tsarist imperium continued to be ruled by a single Russian-dominated political center, albeit one that was at once both utterly different from and curiously continuous with the political order that had preceded it. What allowed for this distinctive historical turn? How and why did a multinational union come to hold sway over much of the space of the old tsarist empire while the spaces of the other dynastic empires of Europe split apart and turned into mosaics of nation-states?

The starting position of the new scholarship has been to acknowledge the basic continuity of the situation: Like the tsarist state it replaced, the USSR was an empire, but it was an empire of a distinctly particular sort. As Yuri Slezkine, one of the most influential scholars in the area of Soviet nationality policy, has argued, "the Soviet Union was an empire in the sense of being big, bad, asymmetrical, hierarchical, and doomed. It was also Utopia in power and a prison of peoples (sentenced to life without parole or death through eventual fusion)" [Slezkine 2000, p.227]. What made it distinct from the normative "colonial empire" that Cold War critics often compared it to, however, was the Soviet government's double commitment to building socialism on the one hand and building up nationality on the other, with both of these commitments in turn linked to a political culture that embraced the application of massive state power, including massive repression, in pursuit of the state's objectives. In this sense, the new scholarship since 1991 shares common ground with the Sovietological writing of the Cold War era - the Soviet government continues to appear as a "breaker" of nations. But, very importantly, the new scholarship also stresses the other side of the Soviet coin: the fact that even as the government "broke" nations, it made them as well. In fact, Slezkine's work has underscored most insightfully of all the pervasive, if selective and shifting, "ethnophilia" of the Soviet regime [Slezkine 1994, p. 414-452].

Key interventions advancing this argument have been made by numerous scholars, in the first instance, Terry Martin, whose study of Soviet nationality policy from the Revolution to the late 1930s, The Affirmative Action Empire, published in 2001, has since become an accepted classic of the field [Martin 2001]. As Martin makes clear, early Soviet leaders threw themselves behind the support of an "ethnoterritorial model" both because they wanted to woo the nationalities of the old tsarist empire and distinguish the USSR from capitalist imperialist states but also because they believed in the essential reality of nationality. They were confident that in time nationality would pass on the road to international proletarian solidarity. But in the meantime national feeling was a reality that required accommodation and practical support. Consequentially, the Soviet government committed itself to the radically innovative policy of "systematically building and strengthening its non-Russian nations, even when they barely existed" [Martin 2001, p.19].

The device to do this was korenizatsiia, variously translated in English as "nativization" or "indigenization." This policy effectively promoted non-Russian national forms 
within the Soviet state - special employment for non-Russians within the state apparatus, special nationally organized territories, instruction in non-Russian languages through elementary and secondary schooling, and the reproduction and diffusion of non-Russian cultures through film, literature, drama, dance, and other artistic forms. As such, korenizatsiia was a policy similar to approaches later embraced in postcolonial India and the US that were known as "affirmative action" because they affirmed the legal and cultural standing of previously exploited ethnic, religious, and racial groups (African-Americans who faced institutional segregation in the United States, for example). For Martin, the USSR was, in effect, the first affirmative-action state, the first government to throw its weight behind repairing the injustices of imperialism through state action. As he makes clear, this commitment to korenizatsiia was the defining leitmotif of the Soviet regime, one that cut across all the apparent divides of the early Soviet period, from the Civil War through the NEP era and the consolidation of Stalin's power, then through the massive violent disruptions of collectivization and the First Five Year Plan and the Terror of the 1930s.

Other influential scholarship takes a similar view, even while debating with some of the particulars of Martin's argument. Francine Hirsch's highly original work on Soviet ethnographers in the 1920s and 1930s, for example, emphasizes korenizatsiia as Sovietization, while underscoring to a greater degree than Martin the continuities between Tsarist Russia and the USSR in regards to creating the corpus of practices and knowledge that affected "nation-building" policy. Hirsch also emphasizes in a way different than Martin the key role played by the non-Russian peoples themselves, ultimately presenting the Sovietstyle process of making nationality as "an interactive and participatory process" involving "non-Russians and Russians alike" [Hirsch 2005, p. 15].

In keeping with the visible works by Martin, Hirsch, and Slezkine, a wave of scholarship since the mid-1990s has helped underscore the vitality of the Soviet nation- and region-making project such that the field now offers works dedicated to a range of discrete Soviet peoples and regional/national sites - Turkmenistan [Edgar 2004], Uzbekistan [Northrop 2004; Khalid 2015; Sartori 2007, p. 115-141; Payne 2001; Ubiria 2015; Haugen 2003], ${ }^{20}$ Kyrgyzstan [Igmen 2012; Loring 2008], the Soviet Roma [O'Keeffe 2013], the Caucasus [Marshall 2010], Jews [Slezkine 2004; Weinberg 1998; Revolution, Repression, and Revival: The Soviet Jewish Experience 2007; Kotlerman 2009; Bemporad 2013; Grüner 2008], the "small peoples of the North" [Slezkine 1994; Ssorin-Chaikov 2003] Ukrainians [Liber 1992; Kuromiya 1998], the Soviet Far East [Shulman 2012; Grant 1995; Bone 1999, p. 59-92; Urbansky 2013], to name just a few; together with attention to a range of themes and topical areas such as the history of language, citizenship, women, medicine, education, and religion [Gorham 2003; Kamp 2006; Kamp 2007, p. 103-114; Kelle 2001; Michaels 2003; Lohr 2014]. Some of the freshest research also focuses on the link between Soviet nationality practices at home and nationality politics abroad, exposing the way that national/imperial considerations such as migration, mixed marriages, and cross-border trade shaped the Soviet experience in borderland zones. Recent scholarship on the Soviet Far East and Manchuria in the 1920s and 1930s is particularly interesting in this regard and suggests the potential for further work under the rubric of transnational and "entan-

20 For references to the considerable Japanese scholarship on the history of Central Asia during the Soviet decades, see the works cited in Uyama Tomohiko [Tomohiko 2015, p. 331-344]. 
gled history" (l'histoire croisée) [Urbansky 2014; Patrikeef 2002; Harbin and Manchuria: Place, Space, and Identity 2000]. ${ }^{21}$

A consideration of the politics of nationality, including NKVD repression of "diaspora nationalities" such as Finns, Chinese, Poles, Germans, and other groups that had presumed ties to peoples beyond Soviet borders, has also emerged an essential aspect of studies of the Terror and the broader functioning of the Stalin dictatorship in the 1930s [Baberowski 2003; Werth url: http://www.massviolence.org/ (Last consulted: December 2015); Khlevniuk 2000, p.159-173; Kuromiya 1998, p. 201-250; Martin 1998, p. 813-861; Petrov, Roginskii 2003, p. 153-172]. Meanwhile the view once widely accepted in the West that the Soviet state intentionally pursued a genocidal famine in Soviet Ukraine has also been challenged and substantially revised, though disagreements continue. ${ }^{22}$

New scholarship has also taken up the explosive nationality issues that relate to the history of the Nazi-Soviet Pact and the war years that followed. Though there is little debate in Western scholarship over the inherently imperialist nature of Stalinist foreign policy toward the Baltic States and Poland between 1939 and 1941 as well as the USSR's more defensive position vis-à-vis Japan in Mongolia and Manchuria, disagreements remain over the numbers of Poles and Balts repressed by Soviet authorities and over the extent and nature of the collaboration between Nazi and Soviet authorities as well as their mutual perceptions. ${ }^{23}$ Studies emphasize the repressive deportations of Soviet nationalities suspected of collaboration during the German occupation (Chechens, Ingush, Kalmyks, Crimean Tatars, and others), the wartime experience of different Soviet nationalities, including the Nazi destruction of Soviet Jewry in German-occupied Ukraine, Belarus, and the Baltic, as well as the consolidation of a more overtly Russian-centered patriotism during the war years [Naimark 2002, pp. 85-107; Burds 2007, pp. 265-312; Werth 2006, pp. 347-366; Dufaud 2007, pp. 151-162; Lower 2007; Beorn 2013; Berkhoff 2008; The Holocaust in the East: Local Perpetrators and Soviet Responses 2014; Soviet Jews in World War II: Fighting, Witnessing, Remembering 2014; Berkhoff 2012); Michaels 2001, pp. 217-235; Brandenberger 2002; Wiener 2002].

Finally, the literature on postwar Stalinism has added to our understanding of a "return to normalcy" in regards to nationality affairs, including attention to "postwar pacifications" by Soviet power in regions with anti-Soviet resistance such as western Ukraine, the role of nationality politics in veterans' affairs, family life, and postwar reconstruction, and official anti-Semitism (in particular, in relation to the so-called Doctors' Plot) [Brent

21 On the rich potential offered by transnational perspectives for rethinking Russian and Soviet history, see [David-Fox 2011, p. 885-904].

22 One of the first works of Western scholarship to "call for a revision of the genocide interpretation" was Mark B. Tauger [Tauger 1991, p. 70-89]. Terry Martin also suggests a more complicated view of how nationality issues shaped the horrors of collectivization in Ukraine, arguing against the idea that the famine represents an intentional act of genocide targeting Ukrainians, but noting that "the gradual emergence of an anti-korenizatsiia hard-line" within Soviet nationality policy in the early 1930s led the government to view the intense resistance to the "grain requisitions crisis in Ukraine and Kuban" as evidence of "Ukrainianization," which then had to be stamped out as anti-Soviet. [Martin 2001, p. 305].

23 See, inter alia, [Gross 1988; Senn 2007; Shared History - Divided Memory: Jews and Others in Soviet-Occupied Poland, 1939-1941 2007; Haslam 1992; Clark, Schlögel 2009, pp. 396-442; David-Fox, Holquist, Martin 2012, pp. 1-12]. And Amir Weiner's extensive critique of Timothy Snyder's influential but controversial work Bloodlands: Europe Between Hitler and Stalin: "Bloodlands, or a Bloody Nose to History? Timothy Snyder's Bloodlands [Weiner 2012]. 
2010; Levene 2012, pp. 303-360; Risch 2011; Yekelchyk 2004; Yekelchyk 2001, pp. 255275; Qualls 2009; Edgar 2007, pp. 581-599]

\section{Conclusion}

Though research on the history of nationality during the 1917-1953 period is diverse and hard to summarize, the sheer volume of the scholarship suggests perhaps the most noteworthy development of all. Prior to the late 1980s, Western research on the national question in the Soviet context was at best peripheral to the field. Today it is undeniably central, having become one of the most dynamic research areas in Western scholarship on the history of Russian Eurasia.

Indeed, if a generation ago one might have been able to relegate discussion of the multinational character of the USSR to a chapter - or even a section of a chapter within a broader history of the Soviet era, such an approach today would appear odd, even ignorant. Arguably the most important breakthrough achieved by Western scholarship in this area over the last generation has been to underscore the profound importance of the topic for Western understandings of the country. It's simply no longer possible to elide the ethnocultural diversity of the Soviet state by lazily conflating Russia with the USSR. Nor can one simply dismiss the Soviet state as a destroyer of nations since it was as much a builder of nations as well.

The paradoxes of Soviet policy and practice regarding the "national question" have yet to be fully explained, and indeed it's possible that a full explanation for the contradictions will always elude us. But it's fair to say that we now know much more about what it meant to be "national" during the formative decades of the Soviet era. The concepts of "nation" and "empire" have been critiqued in new ways and approached through new materials and new vantage points. The result is a remarkably vibrant and rich field of historical inquiry.

\section{References}

Benningsen A. Islam in the Soviet Union. London, New York, Praeger, 1967. 272 pp.

Benningsen A., Quelquejay C. Les mouvements nationaux chez les musulmans de Russie: le Sultangalievisme au Tatarstan. Paris, Mouton, 1960. 284 pp.

Benningsen A. The Evolution of the Muslim Nationalities in the USSR and their Linguistic Problems. London, Central Asian Research Centre, 1961. 57 pp.

Benningsen A., Wimbush E. S. Muslim National Communism in the Soviet Union: A Revolutionary Strategy for the Colonial World. Chicago, University of Chicago Press, 1970. $267 \mathrm{pp}$.

Benningsen A., Wimbush E. S. Mystics and Commissars: Sufism in the Soviet Union. London, Berkeley, Hurst, 1985. $195 \mathrm{pp}$.

Carrère d'Encausse H. Réforme et révolution chez les musulmans de l'Empire russe. Paris, Armand Colin, 1963. $313 \mathrm{pp}$.

Carrère d'Encausse H. L’Empire éclaté: la révolte des nations en U.R. S. S. Paris, Flammarion, 1978. 314 pp.

David-Fox M., Holquist P., Martin A. The Imperial Turn. Kritika: Explorations in Russian and Eurasian History, vol. 7, 4. 2006, pp. 705-712.

Hagen Mark Von. Empires, Borderlands, Diasporas: Eurasia as Anti-Paradigm for the Post-Soviet Era. American Historical Review, vol. 109, 2 .2004, p. 448.

Jennison Earl W., Jr. The Neglected 'Ethnics' in Russian History Surveys. The Historian, vol. 8, 3. 1975. pp. 437-451.

Pipes R. The Formation of the Soviet Union: Communism and Nationalism, 1917-1923. Cambridge, Mass, Harvard University Press, 1954. 355 pp.

Young G. Fetishizing the Soviet Collapse: Historical Rupture and the Historiography of (Early) Soviet Socialism. The Russian Review, vol. 66, 1. 2007, pp. 95-122. 
Laitin David D. Review: The National Uprisings in the Soviet Union. World Politics, vol.44, 1. 1991, pp. 139-177.

Suny R. G. Rethinking Soviet Studies: Bringing the Non-Russians Back In. Beyond Soviet Studies. Ed. by Daniel Orlovsky. Washington, D. C., 1995, pp. 105-147.

Olcott M. B. Soviet Nationality Studies Between Past and Future. Beyond Soviet Studies. Ed. by Daniel Orlovsky. Washington, D. C., 1995, pp. 135-148.

Conquest R. The Nation Killers: The Soviet Deportation of Nationalities. London, Macmillan, 1970. 222 pp.

Conquest R.The Harvest of Sorrow: Soviet Collectivization and the Terror-Famine. New York, Oxford University Press, 1987. $411 \mathrm{pp}$.

Rorlich Azade-Ayşe. The Volga Tatars: A Profile in National Resilience. Stanford, Hoover Institution Press, 1986. 288 pp.

Natsional'nyi vopros i sotsial-demokratiia. Prosveshchenie, 1913. nos. 3, 4, 5.

National'nyi vopros i marksizm. St. Petersburg, Priboi Publ., 1914.

Gorbachev M.Zhizn' i reform, vol. 1. Moscow, Novosti, 1995. Available at: http://www.gorby.ru/gorbachev/ zhizn_i_reformyl/page_18/(accessed 2.12.2015).

Hagen von M. The Archival Gold Rush and Historical Agendas in the Post-Soviet Era. Slavic Review, vol. 52, 1. 1993, pp. 96-100.

Blitstein Peter A. Researching Nationality Policy in the Archives. Cahiers du monde russe, vol. 40, 1/2. 1999a. pp. 125.

Kotkin S. 1991 and the Russian Revolution: Sources, Conceptual Categories, Analytical Frameworks. Journal of Modern History, 70, 2. 1998. p. 392.

Chernetsky V. On the Russian Archives: An Interview with Sergei V. Mironenko. Slavic Review, 52, 4. 1993. p. 841.

Blitstein Peter A. Selected Bibliography of Recent Published Document Collections on Soviet History. Cahiers du monde russe, 40, 1/2. 1999b, pp. 307-326.

Hroch M. Social Preconditions of National Revival in Europe: A Comparative Analysis of the Social Composition of Patriotic Groups among the Smaller European Nations. Cambridge, Cambridge University Press, 1985. $220 \mathrm{pp}$.

Gellner E. Nations and Nationalism. Ithaca, Cornell University Press, 1983. 152 pp.

Anderson B. Imagined Communities: Reflections on the Origins and Spread of Nationalism. London, Verso, 1983. $160 \mathrm{pp}$.

Smith Anthony D. The Ethnic Origins of Nations. Oxford, New York, Blackwell, 1986. 312 pp.

Smith Anthony D. National Identity. Reno,University of Nevada Press, 1991. 226 pp.

Said Edward W. Orientalism. New York, Pantheon, 1978. 368 pp.

Young R. Postcolonialism: An Historical Introduction. Oxford, Blackwell Publishing, 2001. 178 pp.

Brubaker R. Rethinking Nationhood: Nation as Institutionalized Form, Practical Category, Contingent Event. Contention, vol. 4, 1. 1994, pp.6-7.

Brubakers R. Nationhood and the National Question in the Soviet Union and Post-Soviet Eurasia: An Institutionalist Account. Theory and Society, vol. 23, 1. 1994, pp.47-78.

Brubakers R. Nationalism Reframed: Nationhood and the National Question in the New Europe. New York, Cambridge University Press, 1996. 202 pp.

Kappeler A. Russlands erste Nationalitäten. Das Zarenreich und die Völker der Mittleren Wolga vom 16. bis 19. lahrhundert. Cologne and Vienna: Koln/Wien, 1982. 571 pp.

Kappeler A. Kleine Geschichte der Ukraine. Munich, C. H. Beck, 1994. 295 pp.

Kappeler A. Russland als Vielvölkerreich: Entstehung, Geschichte, Zerfall. Munich, C. H. Beck, 1993. 395 pp.

Kappeler A. Rossiia - mnogonatsional'naia imperiia: nekotorye razmyshleniia vosem' let spustia posle publikatskii knigi [Russia - the multinational empire: some reflections eight years later after the publication of the book]. Ab Imperio, 2000, vol. 1, pp. 15-32.

Rieber A.J.Struggle over the Borderlands. The Legacy of History in the New States of Eurasia. Ed. by S. Frederick Starr. Armonk, New York, M. E. Sharpe, 1994, pp. 61-92.

An Interview with Alfred J. Rieber. Kritika: Explorations in Russian and Eurasian History, vol.10(2), 2009, pp. 227-237.

Suny R. G. The Baku Commune, 1917-1918: Class and Nationality in the Russian Revolution. Princeton: Princeton University Press, 1972. 412 pp.

Suny R. G. The Making of the Georgian Nation. Bloomington, Ind., Indiana University Press, 1988. 418 pp.

Suny R. G. Looking Toward Ararat: Armenia in Modern History. Bloomington, Ind., Indiana University Press, 1993. $289 \mathrm{pp}$.

Kotkin S. Mongol Commonwealth? Exchange and Governance across the Post-Mongol Space. Kritika: Explorations in Russian and Eurasian History, vol.3/4. 2007. p. 519. 
Weeks T.R. Nationality, Empire, and Politics in the Russian Empire and USSR: An Overview of Recent Publications. Available at: http://www.hsozkult.de/literaturereview/id/forschungsberichte-1134 (accessed 00.12.2015)

Stone N. The Eastern Front 1914-1917. London, New York, Penguin, 1998. 348 pp.

Wildman A. K. The End of the Russian Imperial Army. Princeton, Princeton University Press, 1980-1987, 2 vols., 386 p.; 429 pp.

Sanborn J.A. Imperial Apocalypse: The Great War and the Destruction of the Russian Empire. New York, Oxford University Press, 2015. 287 pp.

Liulevicius V. G. War Land on the Eastern Front: Culture, National Identity, and German Occupation in World War I. New York, Cambridge University Press, 2005. 309 pp.

Happel J. Nomadische Lebenswelten und zarische Politik: Der Aufstand in Zentralasien 1916. Stuttgart, Franz Steiner, 2010. $378 \mathrm{pp}$.

Brower D. Turkestan and the Fate of the Russian Empire. London, New York, RoutledgeCurzon, 2003. 213 pp.

Lieven D. The End of Tsarist Russia: The March to World War I and Revolution. New York, Viking, 2015. $426 \mathrm{pp}$.

Lohr E. Nationalizing the Russian Empire: The Campaign Against Enemy Aliens during World War I. Cambridge, Mass., Harvard University Press, 2003. 288 pp.

Jahn H. F. Patriotic Culture in Russia during World War I. Ithaca, New York, Cornell University Press, 1995.

Norris S. M. A War of Images: Russian Popular Prints, Wartime Culture, and National Identity, 1812-1945. Dekalb, Ill.: Northern Illinois University Press, 2006.

The Empire and Nationalism at War. Eds E. Lohr, V. Tolz, A. Semyonov, M.von Hagen. Bloomington, Ind., Slavica, 2014.

Reynolds M. A. Shattering Empires: The Clash and Collapse of the Ottoman and Russian Empires, 1908-1918. New York, Cambridge University Press, 2011. 303 pp.

Roshwald A.Ethnic Nationalism and the Fall of Empire: Central Europe, Russia, and the Middle East, 19141923. London, New York, Routledge, 2001. 273 pp.

Rieber A. J. The Struggle for the Eurasian Borderlands: From the Rise of Early Modern Empires to the End of the First World War. New York, Cambridge University Press, 2014. 640 pp.

Shatterzone of Empires: Coexistence and Violence in the German Habsburg, Russian, and Ottoman Borderlands. Eds O. Bartov, E. D. Weitz. Bloomington, Ind., Indiana University Press, 2013. 528 pp.

Holquist P.Making War, Forging Revolution: Russia's Continuum of Crisis, 1914-1921. Cambridge, Mass.,Harvard University Press, 2002. 359 pp.

After Empire: Multiethnic Societies and Empire-Building. The Soviet Union and the Russian, Ottoman, and Habsburg Empires. Eds Karen Barkey, Mark Von Hagen. Boulder, Colo., Westview Press, 1997. 208 pp.

Suny R. G. The Revenge of the Past: Nationalism, Revolution, and the Collapse of the Soviet Union. Stanford, Stanford University Press, 1993. 200 pp.

Khalid A. Tashkent 1917: Muslim Politics in Revolutionary Turkestan. Slavic Review, 55, 2. 1996, pp. 270296.

Khalid A. Nationalizing the Revolution in Central Asia: The Transformation of Jadidism, 1917-1920. A State of Nations: Empire and Nation-Making in the Age of Lenin and Stalin. Eds R. G. Suny, T. Martin. New York, Oxford University Press, 2001, pp. 145-164.

Schafer D.E. Local Politics and the Birth of the Republic of Bashkortostan, 1919-1920. A State of Nations: Empire and Nation-Making in the Age of Lenin and Stalin. Eds R. G. Suny, T. Martin. New York, Oxford University Press, 2001, pp. 165-190.

Sanborn J. The Genesis of Russian Warlordism: Violence and Governance during the First World War and the Civil War. Contemporary European History, 19, 3. 2010, pp. 195-213.

Buttino M. Central Asia (1916-1920): A Kaleidoscope of Local Revolutions and the Building of the Bolshevik Order. The Empire and Nationalism at War. Bloomington, Ind., Slavica, 2014, pp. 109-136.

Cusco A. Nationalism and War in a Contested Borderland: The Case of Russian Bessarabia (1914-17). The Empire and Nationalism at War. Bloomington, Ind.,Slavica, 2014, pp. 137-162.

Riga L. The Bolsheviks and the Russian Empire. New York, Cambridge University Press, 2014. 313 pp.

Jones S. F. Socialism in Georgian Colors: The European Road to Social Democracy, 1883-1917. Cambridge, Harvard University Press, 2005. 384 pp.

Sunderland W. The Baron's Cloak: A History of the Russian Empire in War and Revolution. Ithaca, New York, Cornell University Press, 2014. 344 pp.

Rieber A. J. Stalin: Man of the Borderlands. American Historical Review, 106/5. 2001, pp. 1677-1691;

Suny R. G. Joseph Stalin (1878-1953). Russia's People of Empire: Life Stories from Eurasia, 1500 to the Present. Eds Stephen M. Norris, Willard Sunderland. Bloomington, Ind., 2012, pp. 243-252. 
Hallez X. Turar Ryskulov: The Career of a Kazakh Revolutionary Leader During the Construction of the New Soviet State, 1917-1926. Collquia Umanistica, 3, 2014, pp. 119-134.

Hirsch F. Empire of Nations: Ethnographic Knowledge and the Making of the Soviet Union. Ithaca, New York, Cornell University Press, 2005. 367 pp.

Cadiot J. Le laboratoire imperial: Russie-URSS 1870-1940. Paris, CNRS Éditions, 2007.

Tolz V. Russia's Own Orient: The Politics of Identity and Oriental Studies in the Late Imperial and Early Soviet Periods. New York, Oxford University Press, 2011. 203 pp.

Siegelbaum L. H., Moch L. P. Broad Is My Native Land: Repertoires and Regimes of Migration in Russia's Twentieth Century. Ithaca, New York, Cornell University Press, 2014. 421 pp.

Graber K.E., Murray J.D. The Local History of an Imperial Category: Language and Religion in Russia's Eastern Borderlands, 1860s-1930s. Slavic Review, 74/1, 2015, pp. 127-152.

Slezkine Y. Imperialism as the Highest Stage of Socialism. The Russian Review, 59/2, 2000, pp. 227.

Slezkine Y. The USSR as a Communal Apartment, or How a Socialist Government Promoted Ethnic Particularism. Slavic Review, 53/2, 1994, pp. 414-452.

Martin T. The Affirmative Action Empire: Nations and Nationalism in the Soviet Union, 1923-1939. Ithaca, New York, Cornell University Press, 2001. 496 pp.

Hirsch F. Empire of Nations: Ethnographic Knowledge and the Making of the Soviet Union. Ithaca, New York, Cornell University Press, 2005. 367 pp.

Edgar A. L. Tribal Nation: The Making of Soviet Turkmenistan. Princeton, Princeton University Press, 2004. 296 pp.

Northrop D. T. Veiled Empire. Gender and Power in Stalinist Central Asia. Ithaca, New York, Cornell University Press, 2004385 pp.

Khalid A. Making Uzbekistan: Nation, Empire, and Revolution in the Early USSR. Ithaca, New York, Cornell University Press, 2015. 415 pp.

Sartori P. Tashkent 1918: Giuristi musulmani e autorità sovietiche contro i 'predicatori del bazar. Annali di Ca' Foscari, 45, 3, Serie orientale 37 (2007), pp. 115-141;

Payne M. J.Stalin's Railroad: Turksib and the Building of Socialism. Pittsburgh, University of Pittsburgh Press, 2001. 384 pp.

Ubiria Gr. Soviet Nation-Building in Central Asia: The Making of the Kazakh and Uzbek Nations. London, Routledge, 2015. 284 pp.

Haugen A. The Establishment of National Republics in Soviet Central Asia. Basingstoke, UK, Palgrave Macmillan, 2003. 276 pp.

Tomohiko U. The Contribution of Central Eurasian Studies to Russian and (Post-)Soviet Studies and Beyond. Kritika, 16/2, 2015, pp. 331-344.

Igmen A. Speaking Soviet with an Accent: Culture and Power in Kyrgyzstan. Pittsburgh, University of Pittsburgh Press, 2012. $236 \mathrm{pp}$.

Loring B. H. Building Socialism in Kyrgyzstan: Nation-Making, Rural Development, and Social Change, 19211932. PhD Diss. Brandeis University, 2008.

O'Keeffe B. New Soviet Gypsies: Nationality, Performance, and Selfhood in the Early Soviet Union. Toronto, University of Toronto Press, 2013. 328 pp.

Marshall A. The Caucasus under Soviet Rule. New York, Routledge, 2010. 387 pp.

Slezkine Y. The Jewish Century. Princeton, Princeton University Press, 2004. 438 pp.

Weinberg R. Stalin's Forgotten Zion: Birobidzhan and the Making of a Soviet Jewish Homeland; an Illustrated History. Berkeley, Los Angeles, University of California Press, 1998. 105 pp.

Revolution, Repression, and Revival: The Soviet Jewish Experience. Eds Z. Gitelman, Y. Roi. Boston, Rowman and Littlefield, 2007. 406 pp.

Kotlerman B. B. In Search of Milk and Honey: The Theater of Soviet Jewish Statehood, 1934-49. Bloomington, Ind., Slavica, 2009. 302 pp.

Bemporad E. Becoming Soviet Jews: The Bolshevik Experiment in Minsk. Bloomington, Ind., Indiana University Press, 2013. 292 pp.

Grüner F. Patrioten und Kosmopoliten. Juden im Sowjetstaat 1941 bis 1953. Cologne, Böhlau, 2008. 559 pp.

Slezkine Y.Artic Mirrors: Russia and the Small Peoples of the North. Ithaca, Cornell University Pres, 1994. 456 pp.

Ssorin-Chaikov N. The Social Life of the State in Subarctic Siberia. Stanford, Stanford University Press, 2003. $261 \mathrm{pp}$.

Liber G. O. Soviet Nationality Policy, Urban Growth, and Identity Change in the Ukrainian SSR, 1923-1934. New York, Cambridge University Press, 1992. 289 pp.

Kuromiya H. Freedom and Terror in the Donbas: A Ukrainian-Russian Borderland, 1870s-1990s. New York, Cambridge University Press, 1998. 357 pp. 
Shulman E. Stalinism on the Frontier of Empire: Women and State Formation in the Soviet Far East. New York, Cambridge University Press, 2012. 260 pp.

Grant B.In the Soviet House of Culture: A Century of Perestroikas. Princeton, Princeton University Press, 1995. $225 \mathrm{pp}$.

Bone J. À la recherche d'un Komsomol perdu: Who Really Built Komsomol'sk-na-Amure, and Why. Revue des Études Slaves, 53/1, 1999, pp.59-92.

Urbansky S. Beyond the Steppe Hill: The Making of the Sino-Russian Border (1890-1990): PhD Diss. University of Konstanz, 2013.

Gorham M. S. Speaking in Soviet Tongues: Language Culture and the Politics of Voice in Revolutionary Russia. DeKalb, Ill., Northern Illinois University Press, 2003.

Kamp M. The New Woman in Uzbekistan: Islam, Modernity, and Unveiling under Communism. Seattle, University of Washington Press, 2006. 332 pp.

Kamp M. The Wedding Feast: Living the New Uzbek Life in the 1930s. Everyday Life in Central Asia: Past and Present. Eds J. Sahadeo, R. Zanca. Bloomington, Ind., Indiana University Press, 2007, pp. 103-114.

Keller S. To Moscow, Not Mecca: The Soviet Campaign Against Islam in Central Asia, 1917-1941. Westport, Conn., Praeger, 2001. 277 pp.

Michaels P. Curative Powers: Medicine and Empire in Stalin's Central Asia. Pittsburgh, University of Pittsburgh Press, 2003. 239 pp.

Lohr E. Russian Citizenship: From Empire to the Soviet Union. Cambridge, Mass., Harvard University Press, 2014. 278 pp.

Urbansky S. Beyond the Steppe Hill. Entangled Histories: The Transcultural Past of Northeast China. Eds F. Grüner, D. Ben-Canaan, I. Prodöhl. Heidelberg and New York, Springer Publishers, 2014.

Patrikeef F. Russian Politics in Exile: The Northeast Asian Balance of Power, 1924-1931. Basingstoke, Eng., Palgrave Macmillan, 2002. 248 pp.

Harbin and Manchuria: Place, Space, and Identity, Special issue of South Atlantic Quarterly. Ed. by Thomas Lahusen, 99/1, 2000. 272 p.

David-Fox M. The Implications of Transnationalism. Kritika, 12/4, 2011, pp. 885-904.

Baberowski J. Der Feind ist überall. Stalinismus im Kaukasus. Munich, Deutsche Verlags-Anstalt, 2003.882 pp.

Werth N. The NKVD Mass Secret National Operations (August 1937 - November 1938). Available at: http:// www.massviolence.org/ (accessed 00.12.2015).

Khlevniuk O. The Reasons for the Great Terror: The Foreign-Political Aspect. Russia in the Age of Wars, 1914-1945. Eds S. Pons, A. Romano. Rome, Annali, 2000, pp. 159-173.

Martin T. The Origins of Soviet Ethnic Cleansing. Journal of Modern History, 70/4, 1998, pp. 813-861

Petrov N., Roginskii A. The Polish Operation of the NKVD, 1937-1938. Stalin's Terror: High Politics and Repression in the Soviet Union. Eds B. McLoughlin, K. McDermott. Basingstoke, Eng., Palgrave Macmillan, 2003, pp. 153-172.

Tauger M. B. The 1932 Harvest and the Famine of 1933. Slavic Review, 50/1, 1991, pp. 70-89.

Gross J. T. Revolution from Abroad: The Soviet Conquest of Poland's Western Ukraine and Western Belorussia. Princeton, Princeton University Press, 1988. 396 pp.

Senn A. E. Lithuania 1940: Revolution from Above. Amsterdam, New York, Rodopi, 2007. 290 pp.

Shared History - Divided Memory: Jews and Others in Soviet-Occupied Poland, 1939-1941. Eds E. Barkan, E. A. Cole, K. Struve. Leipzig, Leipziger Universitätsverlag, 2007. 390 pp.

Haslam J. The Soviet Union and the Threat from the East, 1933-1941. Pittsburgh, University of Pittsburgh Press, 1992. 208 pp.

Clark K., Schlögel K. Mutual Perceptions and Projections: Stalin's Russia in Nazi Germany, Nazi Germany in the Soviet Union. Beyond Totalitarianism: Stalinism and Nazism Compared. Eds Sh. Fitzpatrick, M. Geyer. New York, Cambridge University Press, 2009, pp. 396-442.

David-Fox M., Holquist P., Martin A. Introduction: Entangled Histories in an Age of Extremes. Fascination and Enmity: Russia and Germany as Entangled Histories, 1914-1945. Pittsburgh, University of Pittsburgh Press, 2012, pp. 1-12.

Weiner A. Bloodlands, or a Bloody Nose to History? Timothy Snyder's Bloodlands. Cahiers du monde russe, $53 / 4,2012$, Varia.

Naimark N. Fires of Hatred: Ethnic Cleansing in Twentieth-Century Europe. Cambridge, Mass, Harvard University Press, 2002, pp. 85-107.

Burds J. The Soviet War against "Fifth Columnists": The Case of Chechnya, 1942-1944. Journal of Contemporary History, 42/2, 2007, pp. 265-312.

Werth N. The Chechen Problem: Handling an Awkward Legacy, 1918-1958. Contemporary European History, 15/3, 2006, pp. 347-366. 
Dufaud G. La déportation des Tatars de Crimée et leur vie en exil (1944-1956): Un ethnocide? Vingtième Siècle. Revue d'histoire, no. 96 (Oct. - Dec.), 2007, pp. 151-162.

Lower W.Nazi Empire-Building and the Holocaust in Ukraine. Chapel Hill, University of North Carolina Press, 2007. 307 pp.

Beorn W. W. Marching into Darkness: The Wehrmacht and the Holocaust in Belarus. Cambridge, Mass., Harvard University Press, 2013. 314 pp.

Berkhoff K. S. Harvest of Despair: Life and Death in Ukraine under Nazi Rule. Cambridge, Mass., Belknap Press, 2008. 463 p.

The Holocaust in the East: Local Perpetrators and Soviet Responses. Eds M. David-Fox, P. Holquist. Pittsburgh, University of Pittsburgh Press, 2014. 265 pp.

Soviet Jews in World War II: Fighting, Witnessing, Remembering. Eds H. Murav, G. Estraikh. Boston, Academic Studies Press, 2014. 267 pp.

Berkhoff K. C. Motherland in Danger: Soviet Propaganda during World War II. Cambridge, Mass., Harvard University Press, 2012. 407 pp.

Michaels P. Mobilizing Medicine: Medical Cadres, State Power, and Center-Periphery Relations in Wartime Kazakhstan. Provincial Landscapes: Local Dimensions of Soviet Power, 1917-1953. Ed. by D. J. Raleigh. Pittsburgh, University of Pittsburgh Press, 2001, pp. 217-235.

Brandenberger D. National Bolshevism: Stalinist Mass Culture and the Formation of Modern Russian National Identity, 1931-1956. Cambridge, Mass., Harvard University Press, 2002. 378 pp.

Wiener A.Making Sense of War: The Second World War and the Fate of the Bolshevik Revolution. Princeton, Princeton University Press, 2002. 417 pp.

Brent J., Naumov V. Stalin's Last Crime: The Plot Against the Jewish Doctors, 1948-1953. New York, HarpersCollins, 2010. 399 pp.

Levene M. The Crisis of Genocide. Annihilation: The European Rimlands, vol. 2. New York, Cambridge University Press, 2012, pp. 303-360.

Risch W. J. The Ukrainian West: Culture and the Fate of Empire in Soviet Lviv. Cambridge, Mass., Harvard University Press, 2011. 360 pp.

Yekelchyk S. Stalin's Empire of Memory: Russian-Ukrainian Relations in the Soviet Historical Imagination. Toronto: University of Toronto Press, 2004. $231 \mathrm{pp}$.

Yekelchyk S. Celebrating the Soviet Present: The Zhdanovshchina Campaign in Ukrainian Literature and Arts. Provincial Landscapes. Pittsburgh, 2001, pp. 255-275.

Qualls K. D. From Ruins to Reconstruction: Urban Identity in Sevastopol after World War II. Ithaca, New York, Cornell University Press, 2009. 214 pp.

Edgar A. L. Marriage, Modernity, and the 'Friendship of Nations': Interethnic Intimacy in Post-War Central Asia in Comparative Perspective. Central Asian Survey, 26/4, 2007, pp. 581-599.

For citation: Sunderland W. The USSR as a multinational state from the revolution to the death of Stalin: western scholarship since 1991. Vestnik of Saint Petersburg University. History, 2016, issue 4, pp. $142-$ 158. DOI: $10.21638 / 11701 /$ spbu02.2016.411 